\title{
Factors Predicting the Response to a Vitamin D-Fortified Milk in Healthy Postmenopausal Women
}

\author{
Rebeca Reyes-Garcia ${ }^{1,2}{ }^{\mathbb{D}}$, Antonia Garcia-Martin ${ }^{1,3}$, Santiago Palacios ${ }^{4}$, Nancy Salas 4 , \\ Nicolas Mendoza ${ }^{5}$, Miguel Quesada-Charneco ${ }^{3}{ }^{(}$, Juristo Fonolla ${ }^{6}$, Federico Lara-Villoslada ${ }^{7}$ \\ and Manuel Muñoz-Torres 1,3,8,9,*(D) \\ 1 Centro de Investigación Biomédica en Red sobre Fragilidad y Envejecimiento Saludable (CIBERFES), \\ Instituto de Salud Carlos III, 28029 Madrid, Spain; rebeca.reyes.garcia@gmail.com (R.R.-G.); \\ garciamartin_t@hmail.com (A.G.-M.) \\ 2 Unidad de Endocrinología y Nutrición. Hospital Universitario Torrecárdenas, 04009 Almería, Spain \\ 3 Unidad de Gestión Clínica Endocrinología y Nutrición, Hospital Universitario San Cecilio de Granada, \\ Avenida de la Innovacion, 18016 Granada, Spain; charneco@me.com \\ 4 Palacios Institute of Women's Health, 28029 Madrid, Spain; santiago.palacios@institutopalacios.com (S.P.); \\ nancy.salas@institutopalacios.com (N.S.) \\ 5 Department of Obstetrics and Gynecology, University of Granada, 18016 Granada, Spain; \\ NICOMENDOZA@telefonica.net \\ 6 Nutrition Department, Biosearch S.A, 18016 Granada, Spain; juristo.fonollajoya@biosearchlife.com \\ 7 Research and Development Department of Lactalis Puleva, Nutrition Department, Biosearch S.A, \\ 18004 Granada, Spain; federico.laravilloslada@puleva.es \\ 8 Department of Medicine, University of Granada, 18016 Granada, Spain \\ 9 Instituto de Investigación Biosanitaria (Ibs.GRANADA), 18106 Granada, Spain \\ * Correspondence: mmt@mamuto.es; Tel.: +34-950023000
}

Received: 14 September 2019; Accepted: 25 October 2019; Published: 4 November 2019

\begin{abstract}
Background: Milk products fortified with vitamin D may constitute an alternative to pharmacological supplements for reaching the optimal levels of serum 25-hydroxyvitamin D $[25(\mathrm{OH}) \mathrm{D}]$. Our aim was to analyze the response of serum $25(\mathrm{OH}) \mathrm{D}$ and its predictive factors in postmenopausal healthy women after a dietary intervention with a milk fortified with vitamin $\mathrm{D}$ and calcium. Methods: We designed a prospective study including 305 healthy postmenopausal women who consumed a fortified milk with calcium $(900 \mathrm{mg} / 500 \mathrm{~mL})$ and vitamin D3 (600 IU/500 mL) daily for 24 months. Results: The $25(\mathrm{OH}) \mathrm{D}$ concentrations at 24 months were correlated to weight, to body mass index, to the percentage of fat, triglycerides and to baseline 25(OH)D levels. We found significant differences in the levels of $25(\mathrm{OH}) \mathrm{D}$ at 24 months according to baseline $25(\mathrm{OH}) \mathrm{D}$ levels $(p<0.001)$ and body mass index $(p=0.019)$ expressed at quartiles. Multivariate analysis showed an association between levels of $25(\mathrm{OH}) \mathrm{D}$ after the intervention and at baseline $25(\mathrm{OH}) \mathrm{D}($ Beta $=0.47$, $p<0.001$ ) and percentage of body fat (Beta $=-0.227, p=0.049)$, regardless of the body mass index. Conclusions: In healthy postmenopausal women, the improvement in $25(\mathrm{OH}) \mathrm{D}$ after an intervention with a fortified milk for 24 months depends mainly on the baseline levels of serum $25(\mathrm{OH}) \mathrm{D}$ and on the percentage of body fat.
\end{abstract}

Keywords: Vitamin D; postmenopausal women; obesity; fat mass

\section{Introduction}

The Institute of Medicine (IOM) states that the Recommended Dietary Allowance (RDA) of vitamin D is $15 \mu \mathrm{g}$ (600 IU, international units) for $97.5 \%$ of the population aged 1-70, and $20 \mu \mathrm{g}$ (800 IU) for $97.5 \%$ of the population $>70$ years. These are the recommendations for achieving the 
circulating levels of 25 -hydroxyvitamin $\mathrm{D}(25(\mathrm{OH}) \mathrm{D}) \geq 20 \mathrm{ng} / \mathrm{mL}$ needed to maintain bone health [1]. However, other guidelines recommend serum levels of at least $20-30 \mathrm{ng} / \mathrm{mL}[2,3]$, and according to these recommendations, many people are vitamin D deficient and will need vitamin D supplementation [4]. However, there is an important controversy about the target serum levels of $25(\mathrm{OH}) \mathrm{D}$ that must be reached to achieve the maximum health benefits and how to supplement $25(\mathrm{OH}) \mathrm{D}$ in cases where it is indicated [5].

The consumption of foods fortified with vitamin D is an alternative to treatment with pharmacological supplements to reach the optimal serum levels of $25(\mathrm{OH}) \mathrm{D}$. Factors influencing the response to this strategy constitute an interesting area of research to optimize the nutritional recommendations about fortified foods. Although there is no consensus, several clinical factors have been reported to influence the dose-response relationships between vitamin $\mathrm{D}$ supplementation and serum $25(\mathrm{OH}) \mathrm{D}[6,7]$, such as body weight, percentage of fat, age, baseline 25(OH)D levels, and type and the duration of the intervention. In addition, genetic factors like single nucleotide polymorphisms in the vitamin D-binding protein gene can also be significant [8].

Obesity is one of the main factors related to a lower response after vitamin D supplementation [7]. Different causes have been proposed to explain this finding, one of them is a decreased bioavailability of vitamin $\mathrm{D}_{3}$ from skin and from dietary source due to its deposition in body fat compartments. Also, an increased distribution volume for vitamin D has been proposed. Vitamin D deficiency is related to obesity regardless of age and the latitude, and it is also independent of the cut-offs to define vitamin D deficiency [9]. In the context of the increasing prevalence of obesity in the worldwide population, a better knowledge of the relationship between obesity and vitamin $\mathrm{D}$ after nutritional interventions is of interest.

Therefore, the aim of our study was to evaluate the changes occurring in serum $25(\mathrm{OH}) \mathrm{D}$ levels and their predictive factors in postmenopausal Spanish women after a nutritional intervention with a dairy product fortified with vitamin D.

\section{Materials and Methods}

\subsection{Study Design}

The findings presented in this study are a post-hoc analysis of data from a previously published clinical trial [10]. Here we analyze the predictive factors of response of vitamin D after 24 months of a nutritional intervention with a fortified milk with calcium $(900 \mathrm{mg} / 500 \mathrm{~mL})$ and vitamin D3 $(600 \mathrm{IU} / 500 \mathrm{~mL})$ on serum $25(\mathrm{OH}) \mathrm{D}$. For this analysis, we selected 305 postmenopausal healthy women (mean age $59 \pm 6$ years) who completed 24 months of follow up. Inclusion and exclusion criteria of the study have been previously published [10].

Women consumed the dairy drinks for 24 months $(500 \mathrm{~mL} /$ day, two intakes per day of $250 \mathrm{~mL}$ each), in the context of their usual diet. Counselling about Mediterranean diet and physical activity were provided to all women. The adherence to the intervention was evaluated every three months by telephone calls and empty dairy containers were collected. Compliance with the intervention was above $90 \%$. The dairy drinks were produced in white $1 \mathrm{~L}$ Tetra Bricks by Lactalis Puleva (Granada, Spain).

The study was approved by the Ethics Committee of Hospital Universitario San Cecilio of Granada. All the volunteers provided informed written consent. The study was conducted in accordance with the ethical principles of the Declaration of Helsinki, following the EEC Good Clinical Practice guidelines (July 1996).

\subsection{Anthropometric Measurements}

In the first visit anthropometric measurements were obtained, and also after 24 months of intervention. We measured body weight $(\mathrm{kg})$ using a standard balance beam scale (Seca), and body height $(\mathrm{cm})$ using a precision stadiometer (Seca), attached to the balance beam scale. Obesity was defined as body mass index $>30 \mathrm{~kg} / \mathrm{m}^{2}$. 


\subsection{Body Composition Measurements}

Skeletal muscle mass was estimated from bioelectrical impedance analysis (Tanita BC418) at baseline and at 24 months after the onset of the intervention. This device calculates the percentage of body fat, fat mass, fat-free mass, and the predicted muscle mass, based on the data obtained by Dual-Energy X-ray Absorptiometry (DXA), using Bioelectrical Impedance Analysis with an operating frequency of $50 \mathrm{kHz}$ at 500 1A. Obesity was defined as percentage of fat mass above 35\% [11].

\subsection{Biochemical Parameters}

Blood samples were obtained at 0 and at 24 months after a 12 hour overnight fast. The blood was collected in a SST-Vacutainer (BD) and serum was separated by centrifugation at $3000 \mathrm{rpm}$ for $15 \mathrm{~min}$ at $22-24^{\circ} \mathrm{C}$, then it was divided into aliquots and frozen and stored at $-80{ }^{\circ} \mathrm{C}$ until analysis. Serum total cholesterol, high-density lipoprotein cholesterol (HDL-c), triglycerides (TGs), glucose levels, $\mathrm{HbA}_{1 \mathrm{c}}$, and apo $\mathrm{B}$ were determined by standard automated procedures (Biosystems, Barcelona, Spain). LDL-c was calculated using the Friedewald formula. Serum 25(OH)D levels were measured by chemiluminescence immunoassay from Diasorin (LIAISON ${ }^{\circledR} 25 \mathrm{OH}$ Vitamin D TOTAL Assay).

\subsection{Statistical Analyses}

Data were evaluated for normality and homogeneity of variance, and they are expressed as mean standard \pm deviation. The relationship between serum vitamin $\mathrm{D}$ and biochemical and clinical factors were assessed by univariate analysis. A logistic regression and multiple regression analysis were performed to analyze the association between vitamin $\mathrm{D}$ levels at baseline and the levels found after 24 months of intervention. The variables related to vitamin D after 24 months of intervention (percentage of fat mass, weight, BMI, triglycerides and baseline $25 \mathrm{OH}$ vitamin D) were included as covariates. SPSS software (version 17.0, IBM, Armonk, NY, USA) was used for doing statistical analysis. We considered $p$ values $<0.05$ as significant.

\section{Results}

Baseline clinical characteristics are shown in Table 1 . Mean age was $59.3 \pm 5.9$ years.

Table 1. Characteristics of study subjects at baseline and after 24 months of intervention.

\begin{tabular}{cccc}
\hline & Baseline & 24 months & $p$ \\
\hline Weight $(\mathrm{kg})$ & $70 \pm 11$ & $70 \pm 11$ & 0.5 \\
Body mass index $\left(\mathrm{kg} / \mathrm{m}^{2}\right)$ & $28 \pm 4$ & $28 \pm 4$ & 0.084 \\
Obesity $(\%)$ & 28 & 32 & \\
Overweight $(\%)$ & 47 & 48 & \\
Percentage of fat mass & $37 \pm 5$ & $37 \pm 5$ & 0.047 \\
Serum calcium $(\mathrm{mg} / \mathrm{dL})$ & $9.7 \pm 0.6$ & $9.8 \pm 0.6$ & $<0.001$ \\
Parathyroid hormone $(\mathrm{pg} / \mathrm{mL})$ & $57 \pm 21$ & $58 \pm 20$ & 0.102 \\
25(OH)D $(\mathrm{ng} / \mathrm{mL})$ & $22 \pm 8$ & $25 \pm 6$ & $<0.001$ \\
Total cholesterol $(\mathrm{mg} / \mathrm{dL})$ & $214 \pm 33$ & $208 \pm 32$ & $<0.001$ \\
HDL colesterol $(\mathrm{mg} / \mathrm{dL})$ & $55 \pm 15$ & $55 \pm 14$ & 0.62 \\
LDL colesterol $(\mathrm{mg} / \mathrm{dL})$ & $141 \pm 32$ & $135 \pm 32$ & $<0.001$ \\
Triglycerides $(\mathrm{mg} / \mathrm{dL})$ & $87 \pm 44$ & $88 \pm 46$ & 0.6 \\
\hline
\end{tabular}

\subsection{Changes in Biochemical Parameters}

Serum 25(OH)D concentrations increased significantly at 24 months compared to the baseline values $(25.4 \pm 6.3 \mathrm{ng} / \mathrm{dL}$ vs. $21.7 \pm 8.3 \mathrm{ng} / \mathrm{dL}$, respectively, $p<0.001)$. At baseline, $51.3 \%$ of the women had $25(\mathrm{OH}) \mathrm{D}$ concentrations $>20 \mathrm{ng} / \mathrm{mL}$, and $14.1 \%>30 \mathrm{ng} / \mathrm{mL}$. After 24 months of intervention, we observed a significant increase in the percentage of women with $25(\mathrm{OH}) \mathrm{D}$ levels $>20 \mathrm{ng} / \mathrm{mL}(78.5 \%)$ and $>30 \mathrm{ng} / \mathrm{mL}(18.8 \%)$ compared to baseline, $p<0.001$ for both. 


\subsection{Factors Related to $25(\mathrm{OH})$ D Levels after the Intervention}

Serum 25(OH)D levels at 24 months were correlated to weight $(r=-0.243, p<0.001)$, BMI $(r=-0.177, p=0.006)$, percentage of fat mass $(r=-0.32, p<0.001)$, triglycerides $(r=-0.301, p<0.001)$ and baseline $25(\mathrm{OH}) \mathrm{D}$ levels $(r=0.5, p<0.001)$. (Figure 1$)$. We found statistically significant differences in the levels of $25(\mathrm{OH}) \mathrm{D}$ at 24 months according to baseline $25(\mathrm{OH}) \mathrm{D}(p<0.001)$ and $\mathrm{BMI}(p=0.019)$ distributed by quartiles (Figure 2).
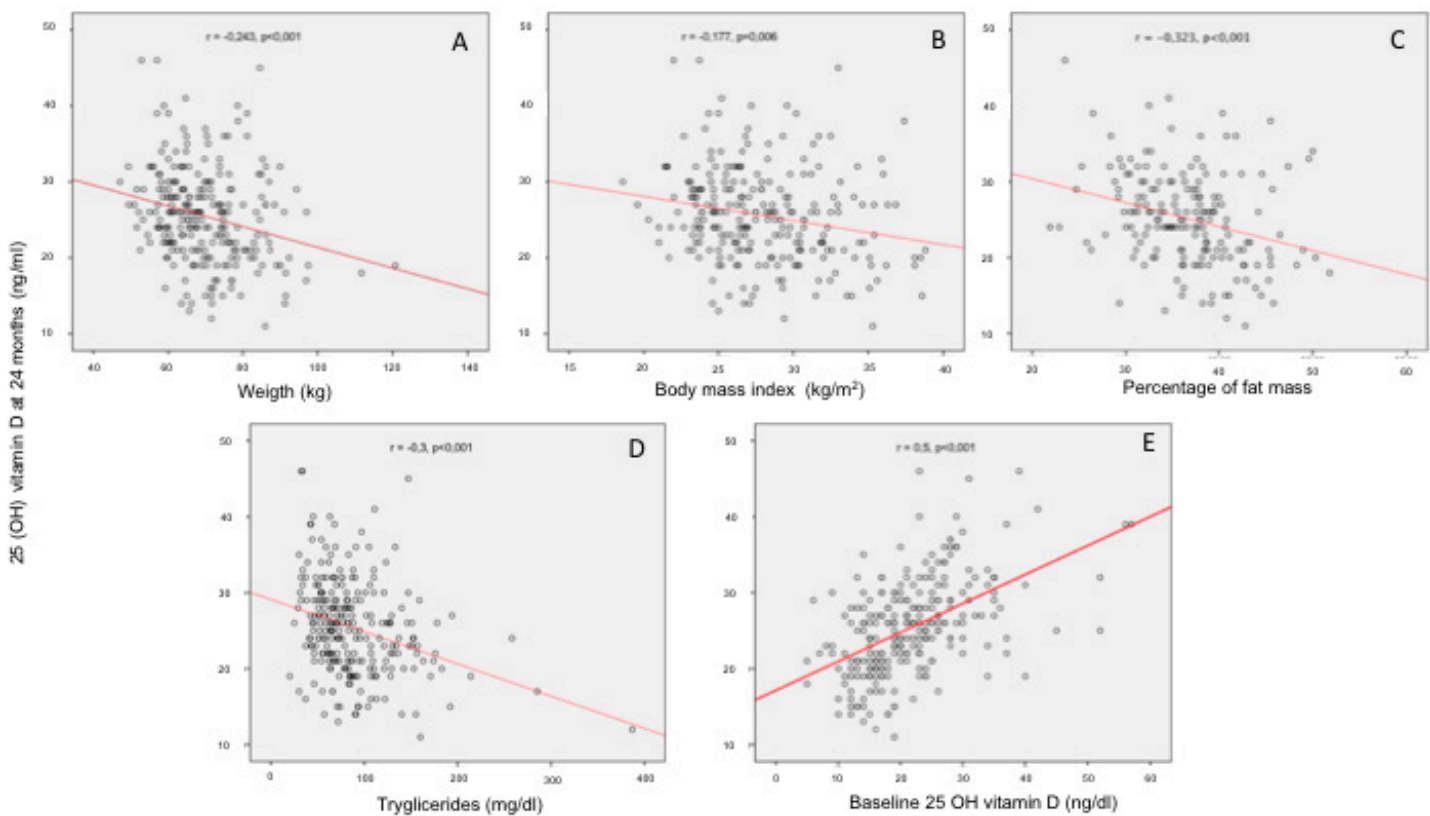

Figure 1. Correlations between serum $25(\mathrm{OH}) \mathrm{D}$ levels at 24 months and weight (A), body mass index (B), percentage of fat mass (C), triglycerides (D) and baseline $25(\mathrm{OH}) \mathrm{D}$ levels (E).
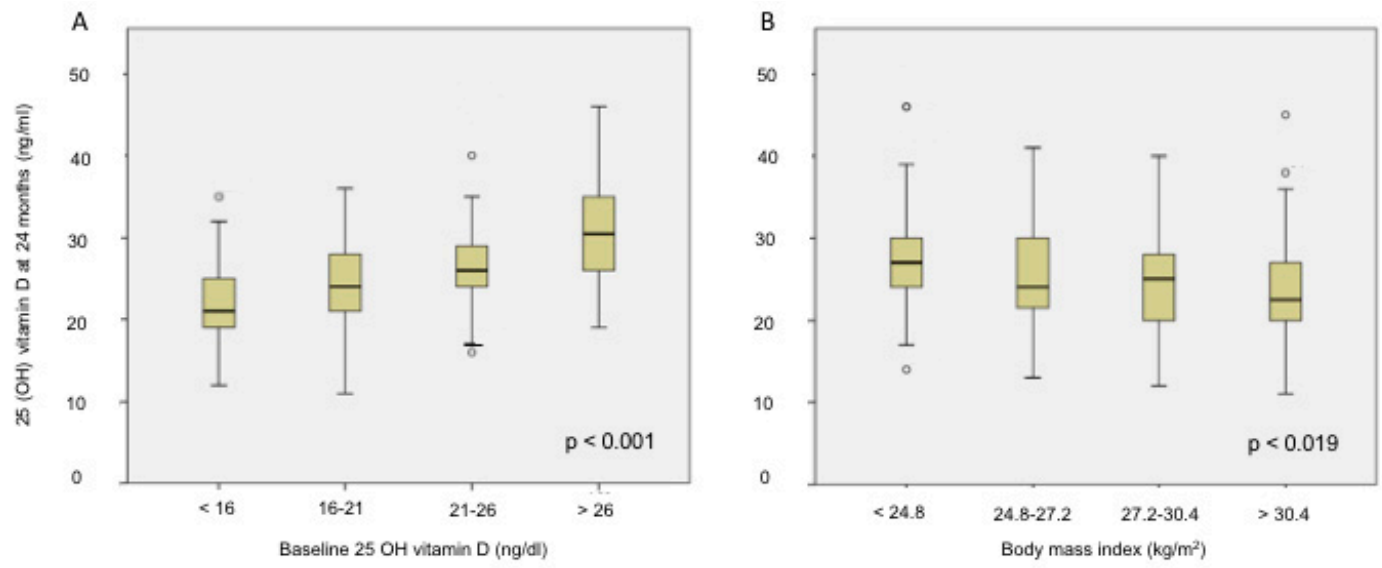

Figure 2. The 25(OH) D levels at 24 months according to quartiles of baseline $25(\mathrm{OH})$ vitamin $\mathrm{D}(\mathbf{A})$ and quartiles of body mass index (B).

We did not find differences in baseline $25(\mathrm{OH}) \mathrm{D}$ according to BMI: $\left(<30 \mathrm{~kg} / \mathrm{m}^{2}\right) 21.9 \pm 8$ vs. $\left(>30 \mathrm{~kg} / \mathrm{m}^{2}\right) 21.3 \pm 8.5, p>0.05$. However, lower $25(\mathrm{OH}) \mathrm{D}$ levels were observed in women with $\mathrm{BMI}>30 \mathrm{~kg} / \mathrm{m}^{2}(24.1 \pm 6.5 \mathrm{ng} / \mathrm{mL})$ vs. those women with a BMI $<30 \mathrm{~kg} / \mathrm{m}^{2}(26.2 \pm 6 \mathrm{ng} / \mathrm{mL})$ at 24 months $(p=0.026)$.

In women with obesity, defined by percentage of fat mass, baseline levels of $25(\mathrm{OH}) \mathrm{D}$ were lower $(21.2 \pm 8.1 \mathrm{ng} / \mathrm{mL})$ compared to women with percentage of fat mass below 35\%: $(24.6 \pm 9 \mathrm{ng} / \mathrm{mL})$, $p<0.01$. Women with obesity, defined by percentage of fat mass, also reached lower $25(\mathrm{OH}) \mathrm{D}$ levels 
after 24 months of intervention: $23.7 \pm 5.9 \mathrm{ng} / \mathrm{mL}$ vs. $27.4 \pm 5.9 \mathrm{ng} / \mathrm{mL}, p<0.001$, compared to women with percentage of fat mass below $35 \%$.

\subsection{Multivariate Analysis}

When we analyzed the probability of reaching adequate vitamin D levels after 24 months of intervention, women with obesity (defined as BMI $>30 \mathrm{~kg} / \mathrm{m}^{2}$ or percentage of fat mass above $35 \%$ ) have a higher risk of $25(\mathrm{OH}) \mathrm{D}<20 \mathrm{ng} / \mathrm{mL}$ at 24 months: odds ratio (OR) 2.3, confidence interval, CI, 95\%: 1.2-4.4, $p=0.013$ for BMI $>30$ and OR 5, CI 95\% 2-12.6, $p<0.001$, for percentage of fat mass. The influence of adiposity, defined as percentage of fat mass, in 25(OH)D levels after 24 months persisted after adjusting for BMI: 25(OH)D $<20 \mathrm{ng} / \mathrm{mL}$ OR $4.5 \mathrm{CI} 95 \% 1.6-12.3, p=0.003,25(\mathrm{OH}) \mathrm{D}<30 \mathrm{ng} / \mathrm{mL}$ OR 3.2 CI 95\% 1.2-8.9, $p=0.02$.

In women with percentage of fat mass above $35 \%$, there was a 3.2 times higher probability of reaching 25(OH)D levels $<30 \mathrm{ng} / \mathrm{dL}$ at 24 months, regardless of the BMI. However, when we adjusted by baseline $25(\mathrm{OH}) \mathrm{D}$ levels, only the relationship with $25(\mathrm{OH}) \mathrm{D}<20 \mathrm{ng} / \mathrm{dL}$ persisted (OR 3.6, CI 1.3-10.1, $p=0.007)$.

In the multivariate analysis, we observed an association between serum $25(\mathrm{OH}) \mathrm{D}$ after 24 months of intervention, baseline $25(\mathrm{OH}) \mathrm{D}$ levels (Beta $=0.47, p<0.001$ ) and percentage of fat mass $($ Beta $=-0.227$, $p=0.049)$, regardless of weight, BMI and triglycerides.

\section{Discussion}

The daily consumption of a dairy product providing $600 \mathrm{IU}$ of vitamin D3 for 24 months is effective to improve serum concentrations of $25(\mathrm{OH}) \mathrm{D}$ in healthy postmenopausal women. The nutritional intervention described in our study allows that $78.5 \%$ of women reach $25(\mathrm{OH}) \mathrm{D}$ levels $>20 \mathrm{ng} / \mathrm{mL}$, and $18.8 \%$ of women reach $25(\mathrm{OH}) \mathrm{D}>30 \mathrm{ng} / \mathrm{mL}$. Baseline $25(\mathrm{OH}) \mathrm{D}$ levels and the percentage of body fat mass are the main factors explaining the responsiveness. The risk of having $25(\mathrm{OH}) \mathrm{D}$ below $20 \mathrm{ng} / \mathrm{mL}$ after 24 months of intervention was 3.6 times higher in the women with fat mass above $35 \%$, regardless of BMI and baseline $25(\mathrm{OH}) \mathrm{D}$ levels.

This study shows that a simple nutritional intervention with a vitamin D3-enriched milk that supplies $600 \mathrm{IU} /$ day is effective in increasing 25(OH)D levels and helps to reach adequate $25(\mathrm{OH}) \mathrm{D}$ levels in a high percentage of women. These results are comparable to those described when pharmacological supplements of vitamin D were used, which often are not well tolerated by patients, especially if combined with calcium [12]. Although there is not a total consistency regarding the adequate $25(\mathrm{OH}) \mathrm{D}$ levels in healthy subjects [1-3,13], the most accepted serum values are $20 \mathrm{ng} / \mathrm{mL}$, which will be reached for most of the women after this intervention.

Basel concentrations of $25(\mathrm{OH}) \mathrm{D}$ influence the achievement of adequate $25(\mathrm{OH}) \mathrm{D}$ levels after 24 months, regardless of other factors. This fact reinforces previous data found in older [14,15] and younger adults [16], and confirms the importance of considering baseline vitamin D in postmenopausal healthy women who receive a nutritional intervention with vitamin D.

Another independent predictor of the response of $25(\mathrm{OH}) \mathrm{D}$ levels after 24 months of intervention was body fat. Although weight, triglycerides and BMI showed and association with 25(OH)D levels at 24 months, only the percentage of fat mass persisted in multivariate analysis. BMI is a simple and worldwide measurement of obesity. However, its validity has been discussed in recent years [17], and other measures of fat may provide a better estimation of obesity, as percentage of fat mass. In the present study, only the percentage of fat mass remained as an independent factor influencing the response of vitamin D after the nutritional intervention, and not BMI. In older healthy women, fat mass was negatively related to $25(\mathrm{OH}) \mathrm{D}$ in a cross-sectional study [18]. Our data showing an independent association between the fat mass percentage and the evolution of $25(\mathrm{OH}) \mathrm{D}$ after 24 months confirms this relationship, and reinforces the utility of this measurement when addressing the response to an intervention with vitamin D. Other authors [16] found that body fat mass and BMI were not related the $25(\mathrm{OH}) \mathrm{D}$ response, speculating that total body mass instead than fat mass may determine the $25(\mathrm{OH}) \mathrm{D}$ 
response. The disparity in the results may be explained by the duration of the intervention and also by the mean BMI of the subjects included in the study.

There is no agreement regarding why obesity would affect serum $25(\mathrm{OH}) \mathrm{D}$ levels. This influence could be explained by a reduced intake of vitamin $\mathrm{D}$, a reduced sun exposure, an increased storage and/or sequestration of vitamin $\mathrm{D}$ in the adipose tissue. A volumetric dilution due to the distribution of $25(\mathrm{OH}) \mathrm{D}$ in larger fat volumes $[6,7,19,20]$. In addition, vitamin $\mathrm{D}$ stored in the adipose tissue may be less available for hydroxylation $[14,16]$. Therefore, if the increased prevalence of obesity worldwide is the explanation for the high rates of hypovitaminosis $\mathrm{D}$ reported is a matter that should be investigated. However, our study could not demonstrate a favorable effect of the consumption of a dairy product supplemented with vitamin D on the loss of body weight or fat mass. This finding is consistent with previously described findings [21].

Although BMI is the most widely used method to evaluate the presence of overweight and obesity, it has been criticized because BMI does not always reflect true body fatness, that may be better evaluated by the assessment of body fat and fat-free mass [22]. Bioelectrical impedance analysis is considered as the simplest, most reproducible and least expensive method for the evaluation of body composition in clinical practice. It has shown a high accuracy and an excellent correlation with DXA when assessing the percentage of body fat [23]. Therefore, bioelectrical impedance is cost-effective and feasible, and may replace DXA in assessing the body composition. Our results highlight the usefulness of bioelectrical impedance analysis in the evaluation of healthy postmenopausal women. This analysis may be useful in the selection of women at higher risk of vitamin D deficiency or in the selection of women who need a higher supplementation of a more frequent evaluation of vitamin D levels.

Our results show that, in healthy postmenopausal women, baseline $25(\mathrm{OH}) \mathrm{D}$ levels and obesity, defined as the percentage of fat mass, are independent determinants of $25(\mathrm{OH}) \mathrm{D}$ levels after 24 months of a nutritional intervention, and they are of clinical relevance. These findings may allow a better personalization of the supplementation with vitamin $\mathrm{D}$ for reaching adequate levels after the intervention. Moreover, it has been described that the response to vitamin D may differ according to the dose of vitamin D and the duration of the intervention [24]. Furthermore, the factors influencing this response may differ between pharmacological and nutritional supplementation, and this potential difference must be addressed. Considering our findings, the recommended vitamin D dose may be adapted to baseline vitamin $\mathrm{D}$ levels. In addition, the estimation of the percentage of fat mass may be better for predicting the response to nutritional interventions with vitamin $\mathrm{D}$.

Our study has several strengths, as the long follow-up for a nutritional intervention, and the exhaustive evaluation of compliance with the intervention. Limitations of the study are the absence of a comprehensive assessment of dietary intake of vitamin $\mathrm{D}$, which may influence the results. However, women were advised not to change their lifestyle habits, and exercise was evaluated semi-quantitatively and showed no changes during the intervention, as an example of no changes. In addition, we evaluated Caucasian healthy women, and the generalization of this finding to males or to other ethnic groups must be confirmed. Moreover, we only measured total $25(\mathrm{OH}) \mathrm{D}$, and we did not evaluate other metabolites.

\section{Conclusions}

In summary, the response of serum $25(\mathrm{OH}) \mathrm{D}$ levels to the supplementation with a fortified milk consumed for 24 months depend on baseline levels of serum 25(OH)D and on the percentage of body fat, regardless of BMI, in healthy postmenopausal women. In these women, the determination of the percentage of fat mass by bioelectrical impedance may allow a better prediction of the response to vitamin $\mathrm{D}$ after a nutritional intervention.

Author Contributions: Designed research: M.M.-T., N.M., S.P., J.F. and F.L.-V.; conducted research: N.M., S.P., N.S., M.Q.-C., M.M.T., R.R.-G., J.F. and F.L.-V.; analyzed data: R.R.-G. and A.G.-M.; wrote the manuscript: R.R.-G. and M.M.-T.; and had the primary responsibility for final content: R.R.-G. and M.M.-T. All authors have approved the final version of the article. 
Funding: This research received no external funding.

Acknowledgments: This study has been financed by Lactalis Puleva. We thank Nutraceutical Translations for English language editing of this manuscript.

Conflicts of Interest: J.F. is an employee at Nutrition Department of Biosearch Life, F.L.-V. is an employee at Research and Development Department of Lactalis Puleva. The rest of the authors have no conflict of interest.

\section{References}

1. Heaney, R.P. Health is better at serum 25(OH)D above 30ng/mL. J. Steroid Biochem. Mol. Biol. 2013, 136, 224-228. [CrossRef] [PubMed]

2. Holick, M.F.; Binkley, N.C.; Bischoff-Ferrari, H.A.; Gordon, C.M.; Hanley, D.A.; Heaney, R.P.; Murad, M.H.; Weaver, C.M. Guidelines for preventing and treating vitamin D deficiency and insufficiency revisited. J. Clin. Endocrinol. Metab. 2012, 97, 1153-1158. [CrossRef] [PubMed]

3. Rosen, C.J.; Abrams, S.A.; Aloia, J.F.; Brannon, P.M.; Clinton, S.K.; Durazo-Arvizu, R.A.; Gallagher, J.C.; Gallo, R.L.; Jones, G.; Kovacs, C.S.; et al. IOM committee members respond to Endocrine Society vitamin D guideline. J. Clin. Endocrinol. Metab. 2012, 97, 1146-1152. [CrossRef] [PubMed]

4. Roth, D.E.; Abrams, S.A.; Aloia, J.; Bergeron, G.; Bourassa, M.W.; Brown, K.H.; Calvo, M.S.; Cashman, K.D.; Combs, G.; De-Regil, L.M.; et al. Global prevalence and disease burden of vitamin D deficiency: A roadmap for action in low- and middle-income countries. Ann N. Y. Acad. Sci. 2018, 430, 44-79. [CrossRef]

5. Giustina, A.; Adler, R.A.; Binkley, N.; Bouillon, R.; Ebeling, P.R.; Lazaretti-Castro, M.; Marcocci, C.; Rizzoli, R.; Sempos, C.T.; Bilezikian, J.P. Controversies in Vitamin D: Summary Statement From an International Conference. J. Clin. Endocrinol. Metab. 2019, 104, 234-240. [CrossRef]

6. Drincic, A.T.; Armas, L.A.G.; Van Diest, E.E.; Heaney, R.P. Volumetric dilution, rather than sequestration best explains the low vitamin D status of obesity. Obes. Silver Spring Md 2012, 20, 1444-1448. [CrossRef]

7. Wortsman, J.; Matsuoka, L.Y.; Chen, T.C.; Lu, Z.; Holick, M.F. Decreased bioavailability of vitamin D in obesity. Am. J. Clin. Nutr. 2000, 72, 690-693. [CrossRef]

8. Didriksen, A.; Grimnes, G.; Hutchinson, M.S.; Kjærgaard, M.; Svartberg, J.; Joakimsen, R.M.; Jorde, R. The serum 25-hydroxyvitamin D response to vitamin D supplementation is related to genetic factors, BMI, and baseline levels. Eur. J. Endocrinol. 2013, 169, 559-567. [CrossRef]

9. Pereira-Santos, M.; Costa, P.R.F.; Assis, A.M.O.; Santos, C.A.S.T.; Santos, D.B. Obesity and vitamin D deficiency: A systematic review and meta-analysis. Obes. Rev. Off. J. Int. Assoc. Study Obes. 2015, 16, 341-349. [CrossRef] [PubMed]

10. Reyes-Garcia, R.; Mendoza, N.; Palacios, S.; Salas, N.; Quesada-Charneco, M.; Garcia-Martin, A.; Fonolla, J.; Lara-Villoslada, F.; Muñoz-Torres, M. Effects of Daily Intake of Calcium and Vitamin D-Enriched Milk in Healthy Postmenopausal Women: A Randomized, Controlled, Double-Blind Nutritional Study. J. Womens Health 2002 2018, 27, 561-568. [CrossRef]

11. De Lorenzo, A.; Deurenberg, P.; Pietrantuono, M.; Di Daniele, N.; Cervelli, V.; Andreoli, A. How fat is obese? Acta Diabetol. 2003, 40 (Suppl. 1), S254-S257. [CrossRef] [PubMed]

12. Sanfelix-Genovés, J.; Gil-Guillén, V.F.; Orozco-Beltran, D.; Giner-Ruiz, V.; Pertusa-Martínez, S.; Reig-Moya, B.; Carratalá, C. Determinant factors of osteoporosis patients' reported therapeutic adherence to calcium and/or vitamin D supplements: A cross-sectional, observational study of postmenopausal women. Drugs Aging 2009, 26, 861-869. [CrossRef] [PubMed]

13. Ross, A.C.; Manson, J.E.; Abrams, S.A.; Aloia, J.F.; Brannon, P.M.; Clinton, S.K.; Durazo-Arvizu, R.A.; Gallagher, J.C.; Gallo, R.L.; Jones, G.; et al. The 2011 report on dietary reference intakes for calcium and vitamin D from the Institute of Medicine: What clinicians need to know. J. Clin. Endocrinol. Metab. 2011, 96, 53-58. [CrossRef] [PubMed]

14. Blum, M.; Dallal, G.E.; Dawson-Hughes, B. Body size and serum 25 hydroxy vitamin D response to oral supplements in healthy older adults. J. Am. Coll. Nutr. 2008, 27, 274-279. [CrossRef]

15. Waterhouse, M.; Tran, B.; Armstrong, B.K.; Baxter, C.; Ebeling, P.R.; English, D.R.; Gebski, V.; Hill, C.; Kimlin, M.G.; Lucas, R.M.; et al. Environmental, personal, and genetic determinants of response to vitamin D supplementation in older adults. J. Clin. Endocrinol. Metab. 2014, 99, E1332-E1340. [CrossRef] 
16. Lehmann, U.; Riedel, A.; Hirche, F.; Brandsch, C.; Girndt, M.; Ulrich, C.; Seibert, E.; Henning, C.; Glomb, M.A.; Dierkes, J.; et al. Vitamin D3 supplementation: Response and predictors of vitamin D3 metabolites-A randomized controlled trial. Clin. Nutr. Edinb. Scotl. 2016, 35, 351-358. [CrossRef]

17. Adab, P.; Pallan, M.; Whincup, P.H. Is BMI the best measure of obesity? BMJ 2018, 360, k1274. [CrossRef]

18. Trevisan, C.; Veronese, N.; Berton, L.; Carraro, S.; Bolzetta, F.; De Rui, M.; Miotto, F.; Inelmen, E.M.; Coin, A.; Perissinotto, E.; et al. Factors Influencing Serum-Hydroxivitamin D Levels and Other Bone Metabolism Parameters in Healthy Older Women. J. Nutr. Health Aging 2017, 21, 131-135. [CrossRef]

19. Jorde, R.; Sneve, M.; Emaus, N.; Figenschau, Y.; Grimnes, G. Cross-sectional and longitudinal relation between serum 25-hydroxyvitamin D and body mass index: The Tromsø study. Eur. J. Nutr. 2010, 49, 401-407. [CrossRef]

20. Carrelli, A.; Bucovsky, M.; Horst, R.; Cremers, S.; Zhang, C.; Bessler, M.; Schrope, B.; Evanko, J.; Blanco, J.; Silverberg, S.J.; et al. Vitamin D Storage in Adipose Tissue of Obese and Normal Weight Women. J. Bone Miner. Res. Off. J. Am. Soc. Bone Miner. Res. 2017, 32, 237-242. [CrossRef]

21. Golzarand, M.; Hollis, B.W.; Mirmiran, P.; Wagner, C.L.; Shab-Bidar, S. Vitamin D supplementation and body fat mass: A systematic review and meta-analysis. Eur. J. Clin. Nutr. 2018, 72, 1345-1357. [CrossRef] [PubMed]

22. Liu, P.; Ma, F.; Lou, H.; Liu, Y. The utility of fat mass index vs. body mass index and percentage of body fat in the screening of metabolic syndrome. BMC Public Health 2013, 13, 629. [CrossRef] [PubMed]

23. Bolanowski, M.; Nilsson, B.E. Assessment of human body composition using dual-energy x-ray absorptiometry and bioelectrical impedance analysis. Med. Sci. Monit. Int. Med. J. Exp. Clin. Res. 2001, 7, 1029-1033.

24. Gallagher, J.C.; Sai, A.; Templin, T.; Smith, L. Dose response to vitamin D supplementation in postmenopausal women: A randomized trial. Ann. Intern. Med. 2012, 156, 425-437. [CrossRef] [PubMed]

(C) 2019 by the authors. Licensee MDPI, Basel, Switzerland. This article is an open access article distributed under the terms and conditions of the Creative Commons Attribution (CC BY) license (http://creativecommons.org/licenses/by/4.0/). 